\title{
E-bogen
}

\section{Skandinaviske perspektiver på forskning og uddannelse}

\author{
Af Gitte Balling, Tor Arne Dahl, Anne Mangen, \\ Skans Kersti Nilsson, Haakon Lund \& Lars Höglund
}

\begin{abstract}
De skandinaviske lande har endnu ikke oplevet den samme udbredelse af e-bogen og påvirkning af bogmarkedet som det er tilfoeldet $i$ de engelsksprogede lande. Alligevel er der en voksende interesse i e-bøger, ikke mindst i forsknings- og folkebibliotekerne.

Denne artikel giver en oversigt over tre skandinaviske biblioteks- og informationsvidenskabelige skoler og deres forskning og undervisning i e-bøger. De respektive institutioner prcesenterer deres aktuelle forskningsinteresser og -perspektiver på e-bøger og digital lcesning, og hvorledes e-bøger er integreret $i$ curriculum og uddannelser.
\end{abstract}

Artiklen ender med at fremhoeve fire områder, som artiklens forfattere mener, kalder på yderligere forskning inden for bibliotek- og informationsvidenskab:

Gitte Balling, Lektor, Københavns Universitet (nts407@iva.ku.dk)

Tor Arne Dahl, Stipendiat, Høgskolen i Oslo og Akershus (Tor-Arne.Dahl@hioa.no)

Anna Mangen, Postdoc, Høgskolen i Oslo og Akershus (anne.mangen@uis.no)

Skans Kersti Nilsson, Universitetslektor, Högskolan i Borås (kersti.nilsson@hb.se)

Haakon Lund, Lektor, Københavns Universitet (hl@iva.dk)

Lars Höglund, Senior professor, Göteborg Universitet (lars.hoglund@jmg.gu.se)
- Deep reading og laseoplevelser på digitale laeseenheder

- Den fysiske bogkulturs betydning for loesere

- Aftalegrundlaget for udlån af e-bøger og ophavsret $i$ biblioteker

- E-bogens integration med andre teknologier

\section{Indledning}

Det litterære landskab er i forandring. Med en ebogslæser i tasken kan vi potentielt have 100 bøger med på stranden, vi kan købe og hente nye udgivelser uanset hvor vi er i verden, og vi kan søge i dokumentet på nye mere smidige måder end i den fysiske bog (Marshall, 2010). Men e-bogen udfordrer også den måde vi hidtil har organiseret bogmarkedet gennem en ændring i produktions-, distributions- og købsadfærd (Hjarvard \& Helles, 2013). Den influerer på det man kan kalde vores bogkultur, hvor vi låner hinanden bøger, sælger dem antikvarisk etc. idet den griber ændrende ind i forhold omkring ejerskab af bøger (Pold, 2012). Og endelig indebærer overgangen fra papir- til skærm-baseret læsning forandringer i selve læsningen som psykologisk proces og oplevelse (Mangen, 2013).

Biblioteks- og informationsvidenskab (B\&I) har i skandinavisk kontekst en lang tradition for at forske og undervise $\mathrm{i}$ informationssystemer og digitale materialer ud fra både et teknologisk og et praksisperspektiv. Forskningen har fokuseret på systemstrukturer og -design, på lagring og genfinding af materialer og på søgeadfærd og -praksis (se for eksempel 
Borlund, Dreier, \& Byström, 2012; Larsen, Ingwersen, \& Kekäläinen, 2006; Pharo \& Nordlie, 2005). Inden for B\&I eksisterer der ligeledes en veletableret litteratursociologisk forskning, som har haft bogmarkedet (Worsøe-Schmidt \& Pedersen, 2002; Worsøe-Schmidt, 1999), litteratur- og bibliotekspolitik (Lindsköld, 2013; Worsøe-Schmidt, 1994a), og ikke mindst læsere og læsning i fokus (Balling, 2009; Mangen, 2013; Nilsson, 2012; Smidt, 2002; Tveit, 2004). Desuden har studier af det fysiske biblioteket som mødeplads, arena for styrkelse af social kapital og som en del af byudviklingen været central (Aabø, Audunson, \& Vårheim, 2010; Aabø \& Audunson, 2012; Audunson, 2005; Dahlkild, 2011; Hvenegaard Rasmussen, Jochumsen, \& Skot-Hansen, 2011).

Mange af de ovennævnte forskningsområder påvirkes radikalt af e-bogen. Således er en ikke uvæsentlig del af folkebibliotekernes arbejde med håndtering af materialer, samarbejde med forlag, udlån og formidling af litteratur til læsere under forandring som følge af digitaliseringen af litteraturen, og de muligheder og udfordringer, det skaber. E-bogen synes at kalde på fornyet forskningsinteresse for fx studier af aftalesystemet mellem forlag og biblioteker, som i sin nuværende form er utidssvarende. Forskning i læsning, læsevaner og litteraturformidling synes ligeledes at kalde på nye perspektiver, hvor fokus flytter sig fra læseoplevelsen af indholdet til oplevelsen af og erfaringen med læseapparatet og med nye litterære former fx i form af de såkaldte enhanced e-books, hvor litteraturen suppleres med lyd, video, animation etc. Disse eksempler peger endvidere på at forskningen i stigende grad har brug for at arbejde på tværs af traditioner og fagområder, både på tværs af fagområder inden for $\mathrm{B} \& \mathrm{I}$, men også i form af tværdiciplinært samarbejde.

Denne artikel udspringer af en samarbejdsworkshop om e-bøger og digital læsning ved Høgskolen i Oslo og Akershus (HiOA) 17.-18. juni 2013 med deltagelse af HiOA, Högskolen i Borås (HB) og Københavns Universitet (KU). Artiklen er baseret på erfaringer og perspektiver fra HiOA, HB og KU. Det er derfor ikke vores hensigt at give et udtømmende billede af forskning og undervisning i e-bogsrelaterede emner i de tre lande, men at komme med en række bud på forskningsemner, pege på muligheder og udfordringer ved undervisning i e-bøger og ikke mindst at identificere, hvor der synes at være et behov for yderligere forskning på e-bogen i relation til B\&I.
Artiklen præsenterer forskningsområder og undervisningspraksis og -erfaring på de tre institutioner. Hvert bidrag indledes med en kort national tilstandsrapport om e-bogsmarkedet og e-bøgernes plads i bibliotekernes tilbud. De tre institutioner har større eller mindre erfaring med at undervise og forske i ebøger, hvilket præger de tre bidrag. Gennemgangen har til formål at danne grundlag for den efterfølgende indkredsning af de forskningsmæssige hvide pletter på landkortet, som vi mener, er væsentlige forskningsområder set fra en biblioteks- og informationsvidenskabelig kontekst.

\section{HiOA - Norge}

I Norge er køb og brug af e-bøger et marginalt fænomen. Kun 1 procent af befolkningen læste en e-bog på en gennemsnitlig dag $\mathrm{i} 2012$, mens 25 procent læste en bog (Vaage, 2013). Boglæsning har ligget stabilt omkring 25 procent siden 1991, mens Internetbrug er steget fra ingenting til 80 procent $i$ samme periode. Den norske e-bogskøber har minimum tre års højere uddannelse, en husstandsindtægt på omkring 1 million norske kroner, er sandsynligvis en kvinde, og regnes ikke som en digital innovatør $^{1}$ (Gran, Figenschou, Gaustad, \& Molde, 2012, s. 125-128).

Til trods for at markedet for e-bøger er småt i dag, forventer mange - ikke mindst i bibliotekssektoren - at e-bøgerne får langt større udbredelse i fremtiden. Mens de norske fagbiblioteker længe har tilbudt store samlinger af e-bøger gennem leverandører som ebrary, EBL, Springer og EBSCO, har folkebibliotekerne i mindre grad kunnet tilbyde det samme. Buskerud-bibliotek med Drammensbiblioteket i spidsen, var først ude med en løsning i 2010, men hidtil har der manglet en forhandlingspartner på vegne af folkebibliotekerne med myndighed til at indgå nationale aftaler. Derfor er den dominerende del af e-bøger i norske folkebiblioteker i dag knyttet til prøveprojektet for parallelindkøb af e-bøger i den særnorske indkøbsordning for ny norsk skønlitteratur for voksne (se Kulturrådet, 2013). 70 e-bogseksemplarer af titler fra 2012-2014 som bliver købt ind af Kulturrådet, vil blive tilbudt gennem de ni biblioteker og bibliotekssammenslutninger som deltager i prøveprojektet. Det findes i dag tre forskellige udlånssystemer $\mathrm{i}$ biblioteker som håndterer e-bøgerne fra denne ordning. Der eksisterer endnu ingen udlånsstatistik, men 
det foreløbige indtryk er at disse titler lånes mere ud som e-bog end på papir².

Udover dette har Nasjonalbibliotekets store scanningsprojekt Bokhylla ${ }^{3}$ været vigtig for at synliggøre norsk litteratur på nettet, men de digitale tekster i slutbrugertjenesten egner sig bedre til søgning og genfinding end til fritidslæsning.

\section{Forskning: Digital læsning}

Ved HiOA er der særlig blevet forsket i hvilke effekter digitalt læseudstyr kan have for kognitive og emotionelle aspekter ved læsning af forskellige typer tekster (skønlitteratur og faglitteratur). En diskussion om hvilke teknologier, der egner sig bedst til læsning, bør forankres i en nuanceret forståelse af hvilke slags tekst der er tale om, og hvad formålet med læsningen er, og at se disse i sammenhæng med de forskellige teknologiers affordances (dvs. brugsegenskaber). E-bogslæsere ${ }^{4}$ er, i modsætning til tabletcomputer ${ }^{5}$, udviklet specielt til at understøtte læsning af lineære, sammenhængende tekster, såsom romaner og fortællinger. Det er derfor ikke overraskende at internationale studier, som sammenligner læsning af lineære tekster på henholdsvis elektronisk blæk- og LCD-display, finder at de to skærmtyper påvirker læseprocessen forskelligt (Kretzschmar mfl., 2013; Siegenthaler, Schmid, Wyss, \& Wurtz, 2012; Siegenthaler, Wurtz, Bergamin, \& Groner, 2011).

I det følgende henvises til en række studier som involverer HiOA forskere, men ofte i form af tværinstitutionelle samarbejdere. En empirisk undersøgelse blandt norske 10. klasse elever viste at læsning af en kort lineær, sammenhængende tekst på PC-skærm kan føre til dårligere læseforståelse end at læse den samme tekst på papir (Mangen, Walgermo, \& Brønnick, 2013). I forlængelse af undersøgelsens påvisning af at der kan være kognitive forskelle knyttet til læsning på hhv. skærm og papir, er det interessant at spørge om det spiller en rolle for emotionelle aspekter ved læsning af fx skønlitteratur at man læser dette på skærmbaserede eller papirbaserede platformer. Foreløbig eksisterer der ikke meget empirisk forskning som kan antyde noget her, men et eksperiment som blev udført af A. Mangen under et forskningsophold i Canada kan nævnes. I dette studie sammenlignede man aspekter ved emotionel indlevelse i en sørgelig fortælling, og om disse varierede afhængig af om man læste fortællingen på en iPad eller på papir.
I tillæg målte man hvorvidt det spillede en rolle for læseoplevelsen om læserne ved de to medier troede at den tekst man læste var fiktion og opdigtet, eller at det var en fortælling baseret på sande hændelser og dermed en nyhedsfortælling. Resultatene viste at læsere som læste en udpræget trist fortælling på papir, og som troede de læste en fortælling som var baseret på sande hændelser, rapporterede størst grad af empati med karaktererne, størst grad af indlevelse, og havde et klarest billede af situationen og hændelser i fortællingen (Mangen \& Kuiken, 2013).

I skrivende stund pågår også de første analyser fra et eksperiment, som går ud på at sammenligne kognitive og emotionelle aspekter ved læsning af en længere (30 sider) mystery-novelle på henholdsvis Kindle og i pocket-bog. Oveni de psykologiske aspekter, er man her også interesseret i at observere ergonomiske, taktile og haptiske aspekter ved personernes læsning og læseoplevelse. Den eventuelle betydning af sådanne dimensioner kan måles ved brug af en såkaldt "haptic dissonance"-skala (Gerlach \& Buxmann, 2011), hvor personer bliver bedt om at rangere betydningen af taktile og haptiske aspekter ved særlig "pleasure reading" (dvs. primært læsning af skønlitteratur for oplevelsens skyld) - som for eksempel "The feel of holding a book is important to me while reading" og "The feel of paper is important to me while turning the page".

Indenfor B\&I er der internationalt også lavet en del forskning på præferencer og oplevelser knyttet til digital læsning, for eksempel på studenters måder at læse og navigere i e-bøger med forskellige typer tekster (Berg, Hoffmann, \& Dawson, 2010; Jeong, 2012; Olsen, Kleivset, \& Langseth, 2013; Pattuelli \& Rabina, 2010; Woody, Daniel, \& Baker, 2010), og på erfaringer med at afprøve e-bogslæsere blandt medlemmer af læseklubber (Landoni \& Hanlon, 2007). Foreløbig er det ikke mange undersøgelser af hvordan yngre læsere takler overgangen fra papir til skærm. Desuden er det svært at få fat i undersøgelser af børn og unges oplevelser ved læsning af skønlitteratur på digitalt læseudstyr. Derfor blev der ved HiOA i 2013 gennemført en undersøgelse, hvor man specielt ville se på unges præferencer, forventninger og oplevelser knyttet til læsning af en roman på henholdsvis e-bogslæser og papir.

Projektet gik ud på at undersøge hvordan et udvalg af unge i Oslo-regionen oplevede at læse (et uddrag 
af) en forventet populær roman på de to forskellige platforme Sony Reader og trykt pocketbog. Der blev afsat midler til at supplere et eksisterende antal elæsere, så det var 28 Sony Reader-e-læsere til disposition i undersøgelsen. Desuden blev der indkøbt 30 stk. pocketudgaver af romanen som elevene skulle læse, Jokeren (1991) af Lars Saabye Christensen. Tre studenter, der var rekrutteret som assistenter fra valgfaget $E$-bøker (se nedenfor), indgik i den indledende fase af projektet $i$ arbejdet med udarbejdelse af forskningsdesign, overvejelser over metodevalg og tilrettelæggelse af teksterne på e-bogslæserne.

Der blev udviklet et todelt spørgeskema, hvor de unge først skulle svare på første del af spørgeskemaet, derefter fik de lov at læse Jokeren på begge platforme, og til slut skulle de svare på sidste del af spørgeskemaet. Læsesessionen midtvejs blev gennemført på den måde at halvdelen af klassen begyndte at læse Jokeren på e-bogslæser, mens den anden halvdel begyndte at læse romanen i pocketbog. Efter femten minutter byttede de med hinanden, og fortsatte læsningen i endnu femten minutter fra den side de var kommet til på den anden platform.

Resultater fra de første analyser (Tveit \& Mangen, 2013) viser at et flertal af respondenterne (56,6 procent) foretrak at læse på e-bogslæser. Dette gjaldt begge køn, og forskellen i favør af e-bogslæser var omtrent lige stor blandt drenge (56,3 procent) som blandt piger (56,9 procent). Yderligere er det værd at bemærke at en relativt stor andel af pigerne $(38,9$ procent) havde en forventning om at de ville komme til at foretrække at læse i bogen, men at mange altså forandrede opfattelse efter læsningen. Mindre overraskende er det måske at et stort flertal af drengene $(59,2$ procent) rapporterede at de forventede at kunne lide e-bogslæseren bedre end bogen. Disse forventninger blev også i stor grad indfriede.

\section{Undervisning: Valgfaget E-bøker}

Foråret 2013 blev valgfaget $E$-bøker introduceret i kursuskataloget for tredje års bachelorstuderende på HiOA. E-bøger har også tidligere været behandlet på bachelor- og masterstudiet, men mere spredt udover de eksisterende obligatoriske kurser (se Dahl, Frisvold, Oterholm, \& Sandberg, 2012 for en oversigt).
I fagbeskrivelsen for valgfaget hedder det:

"Kurset omhandler muligheder og begrænsninger ved produktion, distribution, formidling og anvendelse af e-bøger samt de juridiske og økonomiske rammene for udlån af e-bøger på biblioteket. Kurset har en praktisk og en teoretisk del, og den praktiske del tager udgangspunkt i tekster uden ophavsret."

E-bøger bliver forstået som distribuerbare filer med narrative tekster i denne sammenhæng. Dette er en afgrænset, men pragmatisk definition tilpasset norske forhold i 2013. Hybride, multimediale og hypertekstbaserede formeksperimenter inden for digital litteratur blev bevidst holdt udenfor for ikke at favne for bredt. Det er først og fremmest digitale udgaver af traditionelle papirbøger som i dag er aktuelle i licensforhandlinger i bibliotekssektoren (både fagog folkebiblioteker) og som også skaber de største ændringer på bogmarkedet (jf. Amazons rolle for engelsksproglige bøger).

Todelingen i en praktisk og en teoretisk del var et vigtig pædagogisk princip $i$ undervisningsformen da kurset blev realiseret. I den praktiske del lavede de studerende e-bøger i overensstemmelse med de arbejdsprocesser som Bokselskap benytter ${ }^{6}$. Hver gruppe valgte en tekst fra Nasjonalbibliotekets tjeneste Bokhylla. De tekster som kan downloades fra Bokhylla er i PDF-format som ikke giver gode læseoplevelser på mobile læseplatforme såsom e-bogslæsere og tablets. Bokselskap tilrettelægger denne type tekster til digital læsning ved at tilbyde dem i formaterne EPUB, som er det åbne standardformat for ebøger, og MOBI, som kan læses af Amazons Kindleebogslæser og -apps. Undervisningen blev tilrettelagt som en kodeworkshop over fem sessioner á tre timer. Sessioner blev ledet af den teknisk ansvarlige hos Bokselskap.

Parallelt med kodeworkshoppen blev der afholdt ugentlige forelæsninger gennem hele semesteret. Pensum blev udvalgt i efteråret 2012. Mange aktuelle problemområder knyttet til e-bøger er globale, mens andre har nationale særtræk (for eksempel er udlånsmodellerne forskellige i de skandinaviske lande). Den endelige pensumliste består derfor af rapporter og udredninger om e-bøger i Norge, samt et udvalg videnskabelige artikler fra B\&I-tidsskrifter som var aktuelle og relevante i efteråret 2012. 
To pædagogiske valg viste sig efterfølgende som meget vellykkede. Hands-on-kodeworkshop er det ene. Fem e-bøger blev produceret af de studerende i disse timer $^{7}$. Teksterne indgår nu i Bokselskaps samling af e-bøger. HiOA er angivet som udgiver og de studerendes individuelle navne er nævnt på titelbladet. I evalueringen fik denne del af kurset topscore af alle studerende.

Det andet vellykkede greb var koblingen mellem undervisning og igangværende forskning, som er et ideal i videregående uddannelse, men lettere at realisere på master- end på bachelorniveau.

Det var vanskeligt at finde pensumlitteratur med overordnede teoretiske perspektiver som de studerende kunne bruge i deres individuelle opgaver. Pensumlisten kan derfor fremstå fragmenteret og domineret af empiriske undersøgelser med begrænset holdbarhed i et felt præget af hurtige teknologiske ændringer.

\section{HB -Sverige}

E-bogsmarkedet er endnu forholdsvis lille i Sverige, men vokser hastigt. Den fortsatte udvikling optager såvel bogforlag som biblioteker, forfattere og en række andre aktører og en fortsat stigning forventes. Udlånet af e-bøger via folkebibliotekerne steg mellem 2010 og 2011 med 89 procent til 1,2 millioner lån, hvilket modsvarer omkring to procent af alt udlån med en lineær tilvækst de seneste to år. Samtidigt står bibliotekerne for næsten 90 procent af udbredelsen af e-bøger, eftersom salget af e-bøger endnu er begrænset. Mod den baggrund diskuteres vilkårene for både bibliotekernes og forlagenes e-bogdistribution livligt (Facht, 2012). Bibliotekerne oplever problemer med udgifterne til e-bøger og har indført begrænsninger i udlån og i visse tilfælde har man opsagt aftalen med den dominerende leverandør (Regnell, 2014). E-bogen indgår også i forbindelse med den nye bibliotekslov, hvor det betones at litteratur i såvel fysisk som digitalt format indgår i reglen om afgiftsfrie lån (Bibliotekslag: SFS 2013:801, 2013). I Regeringens forslag 2013/14:3, Läsa för livet (2013/14:3, 2013) (godkendt dec 2013), understøttes Litteraturutredningens (SOU 2012:65, 2012) forslag om blandt andet at Sveriges Kommuner og Landsting bør gå ind som aftalepart på vegne af folkebibliotekerne og at Kungliga Biblioteket gives i opdrag at fremme formidlingen af e-litteratur via biblioteksda- tabasen Libris. Fra og med 2014 uddeler Kulturrådet støtte til udgivelser af kvalitetslitteratur som e-bøger på svensk.

De nordiske lande og andre lande i små sprogområder har specielle forudsætninger pga. bogmarkedernes begrænsede størrelse. E-bogen og den digitale læsning kommer til at påvirke bogmarkedernes aktører langt tid fremover. Fremfor alt handler det ifølge Svedjedal (2012) om kampen om læserne på markedet, særligt dem som endnu ikke har fundet vej til den trykte bog. Den kommercielle del af markedet for e-bøger er endnu ganske uudviklet i vore lande og den største del af e-bøgerne distribueres via bibliotekerne. Samtidigt eksisterer der risici og problemer med den nye teknik, som berører såvel forlagenes og boghandlernes position som læsernes personlige integritet (problemer som disse belyses blandt andet i Bohlund \& Brodin, 2012; Svenska Förläggareföreningen, 2013).

\section{Forskning}

I Sverige gennemføres i øjeblikket en række studier omkring e-bogen, og vi rapporterer her primært fra et større nyt projekt, som finansieres af det svenske Vetenskapsrådet og som gennemføres i samarbejde mellem forskere ved Göteborgs universitet og HB (se nedan). Foruden den her beskrevne forskning gennemføres andre studier som omhandler læsning og ebøger. Her kan nævnes de studier som gennemføres som et postdoc-projekt af Alexandra Borg, "Läsning 2.0. Boken og läsaren i det digitala samhället", som finansieres af Riksbankens Jubileumsfond og Bonnierförlagen (Borg, 2013). Yderligere eksempler er en delstudie i forskningsprojektet "Fiktionsläsningen i internetsamhället: litteraturens betydelse för unga vuxnas personlighetsutveckling och omvärldsorientering" baseret på empiriska data (Nilsson, 2014). Dertil kommer rapporter udgivet af blandt andre Svenska Förläggareföreningen. På opdrag af Riksdagens kulturudvalg er rapporten En bok är en bok är en bok? - en fördjupningsstudie av e-böcker idag (Riksdagen, 2013) udviklet med henblik på at beskrive og analysere e-bogen i Sverige idag.

Forskningsprogrammet "E-bokens framväxt i ett litet språkområde: media, teknologi og effekter i det digitala samhället" er et samarbejde mellem forskere ved Göteborgs universitet og HB, med finansiering af Vetenskapsrådet 2013-2016. Programmet er rettet 
mod studier af e-bogens faktiske og mulige effekter på produktion, publicering, distribution og anvendelse i Sverige. Forskning på dette område er vigtig på grund af en stigning i publiceringen af e-bøger, øget efterspørgsel fra læsere, flere læseplatforme samt stigende udlån af e-bøger fra biblioteket. Samtidigt er forskning i boglæsning i det hele taget væsentligt på grund af unges faldende læsetid og mindskede læseforståelse (se fx SOU 2012:65, 2012, kap. 2).

Sverige har specielle forudsætninger for e-bøger med på den ene side et begrænset marked for det svenske sprog og på den anden side gode sprogkundskaber og omfattende IT-anvendelse. Den aktuelle situation er derfor noget ambivalent og e-bogsmarkedet udenfor biblioteket svag. Samtidigt kan man konstatere at det ikke alene er i små sprogområder, men også i eksempelvis Frankrig og Tyskland at e-bogen endnu er af marginal betydning. Dette er en anden situation end for engelsksprogede lande, og giver ud fra en forskningsmæssig betragtning muligheden for at belyse interessante spørgsmål om hvordan bogindustrien i Sverige bliver påvirket af globaliseringens effekter, hvilke påvirkningsfaktorer, der vil fremkomme i introduktionsfasen og hvilke rolle forskellige aktører vil indtage i e-bogens fortsatte udbredelse.

Den teoretiske ramme for forskningsprojektet indeholder blandt andet en model over innovationsprocesser fra Winston (1998), som særligt fremhæver innovationers fremvækst fra tidlige prototype, forekomsten af sociale og økonomiske faktorer, som gør innovationen "socialt nødvendig" og effekter af faktorer, som virker begrænsende på innovationers "radikale potentiale". Modellen suppleres af blandt andet Bourdieus feltteori til analyser af magtrelationer mellem forskellige aktører på feltet.
Forskningsmetoderne indbefatter interviews med forfattere, forlagschefer og boghandlere; fokusgruppeinterviews med bibliotekarer og læsere samt spørgsmål til offentligheden i nationale survey-undersøgelser i samarbejde med SOM-instituttet og Nordicom.

Nogle præliminære resultater fra projektet bygger på analyser af en survey-undersøgelse blandt 3000 svenskere i den årlige SOM-undersøgelse, hvorfra nedenstående data er hentet (se Bergström \& Höglund, 2013). At læse e-bøger kræver ingen specielle e-bogslæsere eller tablets. Bøgerne er tilgængelige selv på almindelige computere. De potentielle brugere er således betydelige flere end de ca. 19 procent, som har adgang til e-bogslæsere eller tablets i deres husholdning, eftersom mere end 85 procent har adgang til en computer i hjemmet. Så udbredt er læsningen af e-bøger imidlertid ikke blandt den svenske befolkning. Sammenlagt er det i 2012 ni procent som har læst en e-bog - skønlitterær og/eller fagbog inden for det seneste år. Kun et par procent læser en form for e-bog hver uge. Yderligere nogle procent læser hver måned eller kvartal. Omkring fire procent har læst en e-bog på års- eller halvårsbasis (tabel 1). (Samme spørgsmål blev også stillet i 2013 og præliminære resultater viser at yderligere et par procent læste e-bøger det seneste år.)

En nærmere analyse af hvilken type litteratur, der læses som e-bog viser at det er omtrent lige almindeligt at læse skønlitteratur i digital form, 6 procent, som at læse digitale fagbøger, 5 procent.

Undersøgelsen viser at boglæsning varierer mellem forskellige grupper (Bergström \& Höglund, 2013). Endvidere eksisterer der forskellige digitale vaner

\begin{tabular}{|l|c|c|c|}
\hline & E-bog totalt & E-bog, skønlitterær & E-bog, fagbog \\
\hline Aldrig & 91,4 & 93,7 & 95,2 \\
\hline Inden for de seneste 12 mdr. & 2,5 & 2,2 & 1,2 \\
\hline Inden for det seneste halve år & 1,2 & 0,9 & 0,7 \\
\hline Inden for seneste kvartal & 1,2 & 0,9 & 0,8 \\
\hline Inden for sidste måned & 1,4 & 1,1 & 0,7 \\
\hline Inden for sidste uge & 1,4 & 0,7 & 0,9 \\
\hline Flere gange om ugen & 1,0 & 0,7 & 0,5 \\
\hline
\end{tabular}

Tabel 1. E-bogslcesning totalt, skønlittercer bog, fagbog (procent) ${ }^{8}$. Kilde: Den nationale SOM-undersøgelse 2012 
i forskellige grupper. Der findes anledning til at tro at boglæsning varierer afhængigt af traditionelle demografiske faktorer såsom køn, alder og uddannelse, men også afhængigt af generelle læsevaner og eventuelt digitale læsevaner. Læsningen af e-bøger er fem gange så udbredt blandt personer i alderen 16 til 29, som blandt personer som er 65 år eller ældre. Uddannelsesniveau har også her betydning og mønstrene er de samme som ovenfor: e-bogslæsning øger med uddannelsesniveau. Køn har traditionelt stor betydning i det omfang, at kvinder læser mere trykt skønlitteratur end mænd - men dette er noget, som ikke mærkes når det gælder e-bøger, hvor tekniktilgang og teknikinteresse kan have stor betydning. Adgang til e-bogslæser eller tablet er centralt da læsningen på sådanne er den væsentligste måde at læse e-bøger.

Biblioteksvaner har også indflydelse på læsningen af e-bøger. E-bogslæsningen er betydelig mere udbredt blandt dem, som besøger biblioteket og benytter biblioteket på nettet, end blandt dem som ikke gør. Omkring 90 procent af e-bogslæsningen sker via bibliotekslån. En analyse af relationen mellem læsning af trykte bøger og e-bøger viser at tilgangen af gruppen boglæsere gennem e-bøgerne endnu er meget begrænset. Størsteparten af befolkningen, cirka 80 procent, opgiver at de har læst en bog inden for det seneste år, men ikke en e-bog, og de som har læst en e-bog har som regel også læst trykte bøger.

\section{Undervisning}

På HB har spørgsmålet om digitalisering længe indgået som en vigtig del af undervisningen. Digitale biblioteker, digitalisering af kulturarv og andre spørgsmål har haft en central position dels i form af specialiserede kandidatprogrammer med fokus på digitale biblioteker, dels i særskilte kurser. Mens e-bogen som forlagsudgiven digital skønlitteratur først er blevet aktualiseret i de seneste år, har man inden for faglitteratur og på forskningsbiblioteker en længere erfaring med digitaliseringsspørgsmål. De indslag om e-bogen, som indgår i undervisningen i bibliotekaruddannelsen, sker dels i forbindelse med introduktion til emnet gennem en historisk exposé og dels i kurset "Bibliotekens redskap och arbetsmetoder 1" i samarbejde med kurset "Medieplanering" samt i kurset "Biblioteken i samhället 2". Dertil forekommer indslag i valgkurser som "Barn och medier". Et separat kursus om e-bogen findes endnu ikke, hverken på kandidat eller master-nivå.
I kandidatprogrammet Digital Library and Information Services indgår undervisning om materialehåndtering (collection management) $\mathrm{i}$ kurset Digital Library Management. Her indgår separate forelæsninger om e-bøger i folke- og forskningsbiblioteker med seminarie-diskussioner om e-bogen i bibliotekssamlingen. Diskussionerne fokuserer på problemer i relation til forlæggere, forfattere, biblioteker, offentligheden, relevante aktører, lovbestemmelser, hos lokale myndigheder og bibliotekspolicies. Videre gives litteraturstudier og diskussioner om etablerede forretningsmodeller, bestandstilvækst af e-bøger, kilder til nye opdagelser, DRM-spørgsmål og andre praktiske processer og operationer knyttede til kommercielle e-bøger. Digitaliserede bøger for biblioteker og bøger publicerede som open access - ligesom disses potentielle og praktiske anvendelse i bibliotekssammenhæng - diskuteres i begge kurser Digital Library Management og Digitizing cultural heritage material. De studerende er begyndt at vælge e-bøger som emne for deres kandidatspecialer.

\section{KU - Danmark}

I Danmark er køb og brug af e-bøger endnu i sin vorden. I den seneste kulturvaneundersøgelse fra 2012 angives det at 80 procent af den læsende del af befolkningen foretrækker fysiske bøger, mens 8 procent angiver at de læser elektroniske bøger på computer, tablets eller lignende. Ikke overraskende er det den yngste del af befolkningen (15-29 årige) som er mest positive over for e-bøger (Bak, Madsen, Henrichsen, \& Troldborg, 2012). Samme tendens kan ses i den seneste undersøgelse fra 2013 (Hjarvard \& Helles, 2013), hvor de 14-29 årige er de mest ivrige e-bogslæsere. Dog viser undersøgelsen også at en betragtelig andel af alle aldersgrupper læser e-bøger, og at e-bogslæsere synes at have en demografisk profil som stort set minder om læsere af papirbøger (ibid., s. 45).

En forbrugerundersøgelse fra 2012 (YouGov Danmark A/S, 2012) om danskernes forhold til bøger peger i samme retning. Kun 27 procent angiver at de nogensinde har læst en e-bog, og ud af dem bryder kun hver fjerde sig om at læse e-bøger. Danskernes foretrukne e-bogslæser er iPad'en som 42 procent foretrækker at læse e-bøger på. Ifølge undersøgelsen skyldes danskernes tilbageholdenhed over for e-bogen dels prisen, som særligt de yngre læsere mener, burde være væsentlig lavere, og dels at læsning 
associeres med hygge og med duften og vægten af en fysisk bog.

E-bogsmarkedet er stadig småt, men dog voksende. De seneste tal fra det danske bogmarked anslår at det samlede danske e-bogskatalog består af 10.000 titler. I alt blev der solgt eller lånt ca. 1,9 millioner e-bøger og lydbøger i 2012, hvilket er en stigning på 78,7 procent fra lidt over en million i 2011 (Forlæggerforeningen, 2013). Statistikken skelner ikke mellem e-bøger og lydbøger, men de digitale udgivelser anslås at udgøre under 5 procent af de danske forlags samlede omsætning.

De danske folkebiblioteker har de sidste 10 år givet danskerne mulighed for at låne e-bøger. Alligevel er der stadig i dag tale om et væsentligt mindre område sammenlignet med den fysiske bestand. Der findes ikke en officiel statistik over antallet af hhv. fysiske bøger og e-bøger på de danske folkebiblioteker, men det anslås at under 1 procent af de dansksprogede titler er tilgængelige som e-bøger. Hvad angår de fremmedsprogede værker anslås det at knap 20 procent er tilgængelige som e-bøger (Kulturstyrelsen, 2012). Folkebibliotekerne lancerede 2011 en ny national udlånsplatform for e-bøger, eReolen. Der var tale om en transaktionsmodel, dvs. en klikbaseret model, hvor bibliotekerne betaler pr klik/download. eReolen blev en bragende succes blandt landets biblioteksbrugere. Antallet af downloads fra eReolen var i 2012 $2 \frac{1}{2}$ gange større end tekst-downloads af folkebibliotekernes digitale monografier året forinden (Lund \& Worsøe-Schmidt, 2013). Projektet løb i en forsøgsperiode på et år, hvorefter aftalen mellem forlag og biblioteker skulle genforhandles. Forhandlingerne brød hurtigt sammen, og den aktuelle situation er at der i dag eksisterer to udlånsplatforme, eReolen og eBib. Sideløbende med disse forsøgsordninger for udlån af e-bøger er der på kort tid dukket kommercielle all-you-can-eat modeller op, Mofibo og Riidr, hvor læserne på samme vilkår som med musik og film (Spotify, Netflix) for en fast månedlig pris kan få adgang til steaming af e-bøger.

Kaster man blikket på forskningsbibliotekerne og adgangen til fagbøger og tidsskrifter, er historien en anden. Her har digitaliseringen gennem flere årtier forandret arbejdet med håndtering $\mathrm{og}$ formidling af fysiske materialer til i dag at være domineret af håndtering af den digitale infrastruktur. Denne udvikling præges ligeledes af e-bogens fremkomst.
Således satser Det Konglige Bibliotek i København massivt på e-bøger og stiller en halv million titler til rådighed (Høyrup, Nielsen, Hjørland, 2012).

\section{Forskning}

Bogmarkedet: Den litteratursociologiske forskning på KU har traditionelt været centreret omkring bogmarkedet og de politiske aftaler og rammer omkring bogmarkedet. Det gælder såvel forskning i forfatternes vilkår og det historiske bogmarked (Worsøe-Schmidt, 1994a, 1994b), samhandelsregler og bogmarkedsstatistik (Worsøe-Schmidt \& Pedersen, 2002), samt litteraturpolitik (Worsøe-Schmidt, 1999).

Den aktuelle forskning går i samme retning med fokus på hvilke konsekvenser e-bogen har for det danske aftalesystem. Den danske litteraturpolitik har historisk bygget på den antagelse at de kommercielle aktører - forlag og boghandler - var i stand til at klare sig på markedets præmisser, mens forfatterne havde brug for økonomisk støtte og befolkningen havde brug for et gratis alternativ til markedet. Den absolut største litteraturstøtte er derfor biblioteksafgiften, en kompensation for manglende salg af bøger som udbetales til forfatterne en gang om året. Biblioteksafgiften er baseret på antal eksemplarer på folke- og skolebibliotekernes hylder. Da bibliotekerne i de nuværende forretningsmodeller for udlån af e-bøger, ikke indkøber e-bøger, men derimod downloadrettigheder til disse værker, indgår e-bøger ikke i biblioteksafgiften (Lund \& Worsøe-Schmidt, 2013). Aktuelt er der derfor nedsat et udvalg under Kulturministeriet som skal undersøge mulighederne for at inddrage digital litteratur i biblioteksafgiftsordningen.

Undersøgelser viser at den største udfordring for det danske bogmarked, med den aftalestruktur der eksisterer, er ophavsretslovgivningen og bibliotekernes lovmæssige forpligtelse om at stille bøger og andre materialer til rådighed.

Skærmlæsning: Til undersøgelse af hvordan vi læser har eye tracking igennem en årræke været anvendt som forskningsmetode til at afdække øjenbevægelser hos læseren, for derved at opnå viden om læseprocessen og dermed også hvordan vi navigerer igennem en tekst. Eye tracking-studier har givet os en forståelse af nogle af aspekterne ved læsning, men der er stadig en lang række uafklarede spørgsmål 
som danner baggrund for den nuværende forskning indenfor området. Meget af den viden vi har nu om læseprocessen og de kognitive processer der er involveret i samme, er opnået ved at studere læsning af trykt tekst i forskellig form f.eks. ved studier af typer af litteratur og avislæsning (Rayner, 1998).

I kraft af den stadig mere udbredte brug af digitale platforme af alle typer i.e. computer skærm, mobile enheder (tablets, e-bogslæsere, smartphones) er forskningsfokus de sidste 10 år flyttet til at forske i læsning på digitale enheder og dermed af digital fremført tekst. Studier af digital fremført tekster er interessant, da vi som tidligere nævnt har en dyb viden om hvorledes læseprocessen foregår når vi læser tekster i trykt form, men hvorvidt det digitale medie eller den digitale tekstform påvirker læseprocessen er til dels stadig uafklaret.

En række forskningsprojekter på KU har anvendt eye tracking som en del af den anvendte forskningsmetode. Eksempler er studier af relevansbedømmelse af søgeresultater og studier af hvorledes web-sider læses og forstås (Jensen, 2007; Pedersen \& Lund, 2009). Eye tracking-studier af tekstlæsning anvendes også af studerende i forbindelse med større opgaver. Stine Kjær Schmidt undersøgte i forbindelse med sit bachelorprojekt hvorledes der læses på 3 forskellige typer af materialer: Apple iPad, Amazon Kindle DX og tekst trykt på papir. Undersøgelsen anvendte eye tracking som undersøgelsesmetode ved test af alle 3 typer af tekst/materialer og den tekst der blev anvendt $i$ undersøgelsen var i form af en række standardiserede sætninger. Alle enheder anvendte samme skærmstørrelse, font og tekststørrelse. Resultatet af undersøgelsen var, at der ikke kan identificeres nogen forskel i læsemåde mellem de 3 materialetyper og at de forskelle der kan identificeres snarere skyldes individuelle forskelle mellem testpersoners læsemønstre end materialernes forskellighed. Testpersoner udtrykte en stor accept af de digitale enheder som værende læsevenlige (Schmidt, 2011).

\section{Undervisning}

Digitalisering af materialer i relation til bibliotekssamlinger og digitale biblioteker har været en tilbagevendende del af uddannelsen på KU gennem flere år. Fokus har særligt været på digitalisering af kulturarven som har været (og stadig er) et centralt område for megen af den undervisning der udbydes på
KU. På bacheloruddannelsens 4. semester udbydes kurset Digitale biblioteker som introducerer aspekter omkring håndteringen af og adgangen til digitale samlinger i bred forstand. For at give de studerende en mulighed for i praksis at arbejde med implementering af et digital bibliotek introduceres de for opensource softwaret Greenstone. Greenstone kan håndtere alle typer af digitale objekter og giver dermed mulighed også at introducere digitalisering af analoge materialer, tildeling af metadata til digitale objekter, implementering i en database af de digitale objekter, søgeproblematikker og præsentation af digitale objekter i en grænseflade. Et element i kurset Digitale biblioteker er XML og dets anvendelsesmuligheder som opmarkeringssprog af fuldtekstdokumenter og metadata-poster. XML og anvendelsen i forhold til søgning af data introduceres ligeledes og Greenstone bruges som værktøj til at demonstrere hvorledes et system kan anvende XML-opmarkerede data både som input, $\mathrm{i}$ forhold til implementering af søgemaskine og præsentation af data i brugergrænsefladen. Som en del af kurset Digitale biblioteker indgår også undervisning i e-bøger med fokus på tekniske aspekter samt evaluering af grænsefladen til e-bogslæsere.

I foråret 2013 udbød KU et kandidatkursus centreret omkring e-bogen med titlen E-bogen - brudflader, materialitet og oplevelser. Kursets 1 . del blev indledt med en indkredsning af e-bogen som medietype og med diskussioner af, hvordan man kan definere e-bogen og hvad der adskiller e-bogen fra andre digitale tekstformater. Som en indledende del af kurset var der planlagt en workshop, hvor forskellige e-bogslæsere og tablets var tilgængelige for de studerende til afprøvning, for at give dem en fornemmelse af muligheder, begrænsninger og forskelle på forskellige platforme. 2. del af kurset satte fokus på e-bogen og læsning og anlagde et receptionsteoretisk perspektiv. Litteraturgrundlaget satte blandt andet fokus på hvad der sker med læsning når materialiteten ændres fra papir til skærm. 3. del af kurset omhandlede e-bogen og bibliotekerne med fokus på den til tider ophedede debat om ophavsret, der er opstået i kølvandet på bibliotekernes udlån af e-bøger. Afsluttende blev emnet formidling af e-bogen og udfordringer knyttet til formidling af digitale materialer diskuteret.

Den største udfordring ved planlægningen og afholdelsen af kurset var at fremfinde relevant pensumlitteratur, ikke mindst litteratur som kunne understøtte 
diskussioner og analyser af debatten om ophavsret i relationen mellem forlag og biblioteker. Ligeledes var det en svaghed ved kurset at det litteratursociologiske perspektiv var fremherskende, mens det mere teknologiorienterede perspektiv var underprioriteret. Dette skyldtes ikke mindst de underviserkompetencer, som var tilgængelige på kurset.

E-bogskurset blev i 2014 udbudt i en videreudviklet udgave på BA-niveau. I denne udgave er det teknologiske perspektiv blevet opprioriteret i form af kodeworkshops og fælles produktion af en EPUB. Erfaringerne af denne udgave af kurset er i skrivende stund endnu ikke indsamlet.

\section{Diskussion og perspektivering}

Ovenstående gennemgang af den hidtidige undervisningserfaring og -praksis på området viser, at der både på HiOA, KU og HB undervises i e-bogs relaterede emner, enten i form af egentlige kurser om emnet eller i form af problemstillinger knyttet til digitale materialer og digitale biblioteker. Gennemgangen viser ligeledes hvorledes e-bogen som emne kan angribes forskelligt, og bliver behandlet forskelligt, i de tre lande hvilket formentlig skyldes, at undervisningen i e-bøger endnu ikke er en integreret del af curriculum på de biblioteks- og informationsvidenskabelige uddannelser, og derfor udspringer af en personlig interesse blandt underviserne. Det kan være vanskelig at afgrænse begrebet e-bog. Ved $\mathrm{HiOA}$ er den behandlet som en digital ækvivalent til den fysiske papirbog, mens KU har arbejdet ud fra en bredere forståelse af e-bogen som også rummer digital litteratur og interaktive e-bøger/apps. Sådanne forskellige definitioner åbner for meget forskellige problemstillinger.

Et tilsyneladende gennemgående problem er den manglende pensumlitteratur indenfor nogle af de problemstillinger som knytter sig til e-bogen, hvilket antagelig skyldes at der mangler forskning og fokus på disse områder. Et væsentligt spørgsmål at stille på dette sted er imidlertid hvordan undervisning i e-bogsrelaterede emner bør gribes an? Er det frugtbart at udvikle kurser med fokus på e-bøger som på HiOA og KU eller giver det mere mening at integrere emnet i forskellige kurser som man gør på HB? Erfaringer fra KU peger på den ene side på, at man kan samle studerende med en fælles interesse i e-bøger, men at man samtidigt kommer til at lave et kursus, som går i mange forskellige (økonomiske, juridiske, teknologiske og sociologiske) retninger, hvilket kan opleves som fragmenteret blandt de studerende. Her synes erfaringsudveksling og måske sågar samarbejde på tværs af institutioner at være en mulighed. E-bogskurser er netop kendetegnet ved at mange forskellige problemstillinger og dermed mange forskellige fagfelter berøres, hvilket skaber en udfordring for de enkelte undervisere.

Videre genspejler forskellene i tilgange og tematiske afgrænsninger at B\&I, repræsenteret ved $\mathrm{HiOA}, \mathrm{HB}$ og KU, som forskningsområde favner meget bredt. Den forskningsmæssige viden, som eksisterer ligger selvsagt i forlængelse af de forskningstraditioner og -interesser, som institutionernes forskere i forvejen besidder. Således er der en stærk tradition/interesse for på den ene side problemstillinger knyttet til bogmarkedet og læsningen og på den anden side problemstillinger knyttet til digitale materialer/biblioteker. Ikke desto mindre kan der konstateres forskelle i de emner, der forskes i og de metoder, der tages i anvendelse.

På KU har forskningen i digital læsning været fokuseret på skærmlæsning og anvendelse af eyetracking som metode, mens digital læseforskning på HiOA har arbejdet mere tværfagligt og blandt andet haft en mere kognitiv og psykologisk tilgang. På HB baseres forskningen på empirisk dataindsamling, som surveyundersøgelser og forskellige typer af interviews. Den eksisterende viden om e-bogen og digital læsning peger på et behov for at forene de forskningstraditioner som biblioteks- og informationsvidenskaben hviler på, men også at supplere dem med viden fra andre forskningsområder. På baggrund af ovenstående gennemgang af e-bogsrelateret forskning på de tre institutioner og i kraft af vores erfaring med at undervise i e-bøger, har vi opstillet en række emneområder som kalder på en biblioteks- og informationsvidenskabelige forskningsindsats. Dermed mener vi at emnerne alle har stor relevans for B\&I forskning og uddannelser, og at biblioteks- og informationsvidenskaben vil kunne bidrage med væsentlige perspektiver på disse emner. Vi mener også at visse emner kalder på samarbejde med forskere fra andre institutioner eller fagfelter.

- Empiriske studier af deep reading og loeseoplevelser på digitale laseenheder.

Problemstillinger som forener forskning af fag-/ 
forskningsbibliotekernes håndtering af e-bøger og digitalt materiale, og forskning af digital læsning i en folkebibliotek-sammenhæng, er det som i litteraturen kaldes "deep reading", altså en type læsning som kendetegnes ved at kræve fordybning og koncentration over tid, om tekster som er lange og potentielt komplekse, og som typisk både kræver og fremmer refleksion og kontemplation. De forskellige digitale læseenheder har forskellige affordances som kan gøre dem mere eller mindre egnet til "deep reading". E-boglæsere baseret på elektronisk blæk er meget forskellige fra tablets mht. visuel ergonomi. Videre har det betydning hvorvidt og i hvilken grad læseapparatet anvendes til andre aktiviteter end selve læsningen, som for eksempel adgang til internet, mail-applikationer og sociale medier. Det er usandsynligt at denne type multitasking-affordances er særlig kompatibel med kravene til kontemplation og vedvarende fokus på en og samme tekst ved forskellige former for "deep reading". Læsning i en digital tidsalder synes at kalde på, for det første, mere forskning på hvordan og i hvor stor grad læseapparatet forandrer læseoplevelsen blandt forskellige målgrupper (voksne, unge og børn). For det andet er der stort behov for empirisk forskning som undersøger hvilken betydning læseteknologiernes forskellige ergonomiske (herunder visuelle, taktile og haptiske) egenskaber har for vores læsning, forståelse og oplevelse af forskellige typer tekster, til forskellige formål. Her vil særlig tværvidenskabelig empirisk forskning, gerne i samarbejde på tværs af både discipliner og etablerede fakultetsgrænser, om effekter af forskellige teknologiers grænseflade være et nyttig supplement til B\&I-feltets forskningsportefølje.

- Empiriske studier om betydningen af bogkultur for loesere.

Igennem bogens, og måske særligt skønlitteraturens historie har læsere udviklet og forfinet deres omgang med bogen som objekt. Bogsamlinger er ikke alene fysiske genstande i et rum, men rummer også stor symbolsk betydning som igen har betydning for menneskers sociale status og identitet (van der Weel, 2010). Studier viser at bogsamlinger kan have denne betydning også blandt børn (McKechnie, 2004). Ligeledes eksisterer der en etableret kultur omkring private udlån af og salg af bøger gennem antikvariater, marskandisere og på loppemarked. Senest har denne udveksling af brugte bøger fundet ind på hoteller, vandrehjem og på andre offentlige steder. Vi låner bøger til hinanden og deler på den måde læseoplevelser. Ligeledes udgør bogsamlingen for mange læsere en væsentlig del af deres interiør, som igen kan ses som en del af en identitetskonstruktion. Spørgsmålet er hvad digitaliseringen af bogen betyder for denne bogkultur og om bogkulturen ligeledes bliver digitaliseret gennem brug af $\mathrm{fx}$ Library Thing og lignende sociale medieplatforme. Der synes at være et behov for at få afdækket omfanget og betydningen af denne bogkultur blandt læsere, både yngre og ældre.

- Forskning med fokus på aftalegrundlaget for biblioteksudlån og ophavsret.

Digitaliseringen af bøger har betydet at store amerikanske aktører som Apple, Google og Amazon har stor indflydelse på de skandinaviske bogmarkeder. Det har ligeledes betydet at de rammeaftaler, som samarbejdet mellem forlag og biblioteker er grundlagt på, på nogle områder er utidssvarende. Meget af det lovgrundlag og de litteraturstøtteordninger som er blevet opbygget gennem de seneste 100 år kan ikke rumme de muligheder og udfordringer, som digitale bøger rummer. Forskning på dette felt er manglende og nødvendigt, ikke mindst indenfor en biblioteksvidenskabelig forskningstradition, hvor bibliotekers rolle som samfunds- og kulturinstitution har en væsentlig plads.

- Forskning med fokus på e-bogens integration med andre teknologier.

E-bogen er stadig i en tidlig fase i udbredelse i Norden og er først nu ved at etablere sig som et alternativ til traditionelle bøger. Samtidig sker der en stadig teknologisk udvikling af de enheder vi bruger til at læse e-bøger på. Dette betyder at nye interaktionsformer er på vej som et supplement eller en erstatning for den etablerede måde at navigere i en e-bog på. Som et eksempel på dette kan nævnes udvikling af en multimodal e-book reader, hvor en kombination af øjenbevægelser, håndskrift og tale bruges ved interaktion med e-bogslæseren og derved også med e-bogen (El Hosseiny, Biedert, Dengel, \& Buscher, 2011).

E-bogen er endnu et ungt medie, og vi har stadig til gode at se, hvilken indflydelse den vil få på vores læsning, på bogkulturen og på bibliotekernes virke. Ikke desto mindre peger vores erfaringer på, at ebogen skaber en række udfordringer, der kalder på en forskningsmæssig interesse. Biblioteks- og informa- 
tionsvidenskaben rummer i sig selv en tværvidenskabelig tilgang til læsning, litteratur og digitale medier, der synes som en ideel platform for forskning og undervisning i e-bogs relaterede emner.

\section{Noter}

1. Begrebet (digitale) innovatører er hentet fra Rogers (2003), og i rapporten beskrives de som "dristige, nysgerrige, risikotagere som har en lav tærskel for at afprøve og ibrugtage nye ideer og ukendte produkter" (Gran, Figenschou, Gaustad, \& Molde, 2012, s. 23).

2. Personlig kommunikation med Bjørn Kjetil Fredriksen, Stavanger bibliotek, 2013-10-09.

3. Bokhylla: http://www.bokhylla.no/

4. Lesebrett (norsk), e-bogslæser (dansk), läsplatta (svensk): dedikeret læseapparat for e-bøger med skærm baseret på e-blækteknologi uden baggrundslys som også egner sig til læsning i sollys. Eksempler er Amazon Kindle, Sony Reader, NOOK og Kobo.

5. Nettbrett (norsk), tabletcomputer (dansk), surfplatta (svensk): multifunktionelle apparater med LCD-basert trykskærm i farver som tilbyder fuld netadgang. E-bøger læses via installerede apps. Eksempler er Apple iPad, Samsung Galaxy Tab og Amazons Kindle Fire-modell.

6. Bokselskap er et netsted som tilbyder gratis download af norsk litteratur som er uden ophavsret. Se Bokselskaps netsider for nærmere beskrivelse af arbejdsprocessen: http://www.bokselskap.no/ hjelp_om/om_bokselskap

7. De fem e-bøger er: "Fru Evas Dagbog" (1905) af Hulda Garborg, "Sankt Hans Fest" (1887) af Alexander L. Kielland, "Storhertuginnen av speilsalen" (1931) af Stein Riverton, "Streik" (1891) af Per Sivle og "Som kvinder er" (1895) af Dikken Zwilgmeyer.

8. Spørgsmålet lyder Hvor ofte har du i de seneste 12 måneder laest følgende type af bøger? Svarmulighederne var skønlittercer bog respektive fagbog. Skalaen var på 7 trin og kan genfindes i tabellen.

\section{Referencer}

Aabø, S \& Audunson, R (2012). Use of library space and the library as place. Library \& Information Science Research, 34(2), 138-149. http://dx.doi. org/10.1016/j.lisr.2011.06.002

Aabø, S, Audunson, R \& Vårheim, A (2010). How do public libraries function as meeting places? $\mathrm{Li}$ brary \& Information Science Research, 32(1), 1626. http://dx.doi.org/10.1016/j.lisr.2009.07.008

Audunson, R (2005). The public library as a meeting-place in a multicultural and digital context: The necessity of low-intensive meeting-places. Journal of Documentation, 61(3), 429-441. http://dx.doi. org/10.1108/00220410510598562

Bak, L, Madsen, AS, Henrichsen, B \& Troldborg, S (2012). Danskernes kulturvaner 2012. København: Kulturministeriet. Hentet fra http://kum.dk/Documents/Publikationer/2012/endelig_danskernes_kulturvaner_pdfa.pdf

Balling, G (2009). Littercer cestetisk oplevelse: Laesning, loeseoplevelser og loeseundersøgelser: en diskussion af teoretiske og metodiske problemstillinger (PhDafhandling, Danmarks biblioteksskole). København: Danmarks Bibkioteksskole.

Berg, SA, Hoffmann, K \& Dawson, D (2010). Not on the same page: Undergraduates' information retrieval in electronic and print books. The Journal of Academic Librarianship, 36(6), 518-525. http:// dx.doi.org/10.1016/j.acalib.2010.08.008

Bergström, A \& Höglund, L (2013). Tidiga läsare av e-böcker. I L. Weibull, H. Oscarsson, \& A. Bergström (Red.), Vägskäl: 43 kapitel om politik, medier och samhälle : SOM-undersökningen 2012 (s. 357367). Göteborg: SOM-institutet. Hentet fra http:// www.som.gu.se/digitalAssets/1453/1453863_22bergstr--m-o-h--glund--e-b--cker.pdf

Bibliotekslag: SFS 2013:801 (2013). Stockholm: Riksdagen, Kulturdepartementet. Hentet fra http:// www.riksdagen.se/sv/Dokument-Lagar/Lagar/ Svenskforfattningssamling/Bibliotekslag-2013801_ sfs-2013-801/ 
Bohlund, K \& Brodin, B (2012). Bokmarknaden 2012. Stockholm: Svenska Förläggareföreningen/ Svenska Bokhandlareföreningen. Hentet fra http:// forlaggare.se/sites/default/files/Bokmarknaden $\% 20$ 2012\%20rapport_0.pdf

Borg, A (2013). Läsning i den digitala tidsåldern. I J. Björkman \& B. Fjæstad (Red.), Läsning, RJ:s årsbok (s. 165-175). Göteborg: Makadam.

Borlund, P, Dreier, S \& Byström, K (2012). What does time spent on searching indicate? Proceedings of the 4th Information Interaction in Context Symposium, IIIX '12 (s. 184-193). New York, NY: ACM. http://dx.doi.org/10.1145/2362724.2362756

Dahl, TA, Frisvold, Ø, Oterholm, K \& Sandberg, A (2012, 29. april). E-bokverkstedet: Sluttrapport. Høgskolen i Oslo og Akershus, Institutt for arkiv-, bibliotek- og informasjonsvitenskap. Hentet fra http://ebokverkstedet.HiOA.no/wp-content/ uploads/2012/04/e-bokverkstedet_rapport.pdf

Dahlkild, N (2011). Biblioteket i tid og rum: Arkitektur, indretning og formidling. København: Danmarks Biblioteksforening.

El Hosseiny, M, Biedert, R, Dengel, A \& Buscher, G (2011). The eyePad: Tom Riddle in the 21st century. Proceedings of the 2nd Workshop on Eye Gaze in Intelligent Human Machine Interaction held in conjunction with IUI 2011.

Facht, U (2012). Aktuell statistik om e-böcker. I U. Carlsson \& J. Johannisson (Red.), Läsarnas marknad, marknadens läsare: En forskningsantologi utarbetad för Litteraturutredningen (s. 231-240). Göteborg: Nordicom.

Forlæggerforeningen (2013). Arsstatistik 2012. København: Forlæggerforeningen. 22. april. Hentet fra http://www.danskeforlag.dk/download/ pdf/016iak999_Forl\%C3\%A6ggerforeningens_\%C3 \%85rsstatistik_2012.pdf

Gerlach, J \& Buxmann, P (2011). Investigating the acceptance of electronic books: The impact of haptic dissonance on innovation adoption. ECIS 2011 Proceedings. Hentet fra http://aisel.aisnet.org/cgi/viewcontent. . gi $?$ article $=1140 \&$ context $=$ ecis 2011
Gran, AB, Figenschou, A, Gaustad, T \& Molde, A (2012). Digitalt kulturkonsum: En norsk studie (Forskningsrapport No. 2/2012). Oslo: Handelshøyskolen BI, Institutt for kommunikasjon, kultur og språk. Hentet fra http://web.bi.no/forskning/papers. nsf/b63c43a0385ff61dc1256e620043c6b0/d384e 2d6a16ca024c1257af30031 ecc5/\$FILE/2012-02Gran\%20et\%20al.pdf

Hjarvard, S \& Helles, R (2013). Digital books on the point of take-off? The ebook in Denmark anno 2013. Akademisk kvarter/Academic Quarter, 7, 34-50.

Hvenegaard Rasmussen, C, Jochumsen, H \& SkotHansen, D (2011). Biblioteket i byudviklingen: Oplevelse, kreativitet og innovation. København: Danmarks Biblioteksforening.

Høyrup, H, Nielsen, HJ \& Hjørland, B (red.) (2012). Viden $i$ spil. Forskningsbibliotekernes funktioner $i$ forandring. København: Samfundslitteratur.

Jensen, JMB (2007). Er der relevans i øjet der ser? En undersøgelse af anvendeligheden af eye tracking i forbindelse med implicit relevans feedback (Masteropgave, Danmarks Biblioteksskole). København: Danmarks Biblioteksskole.

Jeong, H (2012). A comparison of the influence of electronic books and paper books on reading comprehension, eye fatigue, and perception. The Electronic Library, 30(3), 390-408. http://dx.doi. org/10.1108/02640471211241663

Kretzschmar, F, Pleimling, D, Hosemann, J, Füssel, S, Bornkessel-Schlesewsky, I \& Schlesewsky, M (2013). Subjective impressions do not mirror online reading effort: Concurrent EEG-eyetracking evidence from the reading of books and digital media. PLoS ONE, 8(2), e56178. http://dx.doi.org/10.1371/journal.pone. 0056178

Kulturrådet (2013). Innkjøpsordning for: Ny skjønnlitteratur for vaksne. Hentet 13. august 2013 fra http://kulturradet.no/stotteordninger/skjonnlitteraturfor-vaksne

Kulturstyrelsen (2012). Rapport om e-bogens udvikling på folkebibliotekerne. København: Kulturstyrelsen for Kulturministeriet. Hentet fra http://kum.dk/ Documents/Publikationer/2012/Rapport\%20-\%20 
e-bogens $\% 20$ udvikling $\% 20 \mathrm{p} \% \mathrm{C} 3 \% \mathrm{~A} 5 \% 20$ folkebibliotekerne.pdf

Landoni, M \& Hanlon, G (2007). E-book reading groups: Interacting with e-books in public libraries. The Electronic Library, 25(5), 599-612. http:// dx.doi.org/10.1108/02640470710829578

Larsen, B, Ingwersen, P \& Kekäläinen, J (2006). The polyrepresentation continuum in IR. Proceedings of the 1st International Conference on Information Interaction in Context, IIiX (s. 8896). New York, NY, USA: ACM. http://dx.doi. org/10.1145/1164820.1164840

Lindsköld, L (2013). Betydelsen av kvalitet: En studie av diskursen om statens stöd till ny, svensk skönlitteratur 1975-2009 (PhDafhandling, Högskolan i Borås, Sverige). Hentet fra http://hdl.handle. net/2320/12610

Lund, ND \& Worsøe-Schmidt, L (2013). To udfordringer for dansk litteraturpolitik: Når litteratur går fra fast til flydende form. Præsenteret på NCCPR 2013, København 14.-16. august 2013.

Läsa för livet (2013). Stockholm: Kulturdepartementet. (2013/14:3) 26. september. Hentet fra http:// www.regeringen.se/sb/d/16860/a/224959

Mangen, A (2013). "Putting the body back into reading": Kropp og hjerne, lesing og grensesnitt. Cursiv, (11), 11-31.

Mangen, A \& Kuiken, D (2013). Lost in an iPad: Immersive reading on paper and tablet. Sendt utgiver, under vurdering.

Mangen, A, Walgermo, BR \& Brønnick, K (2013). Reading linear texts on paper versus computer screen: Effects on reading comprehension. International Journal of Educational Research, 58, 61-68. http://dx.doi.org/10.1016/j.ijer.2012.12.002

Marshall, CC (2010). Reading and writing the electronic book. San Rafael, CA: Morgan and Claypool.

McKechnie, LEF (2004). "I'll keep them for my children" (Kevin, nine years) : Children's personal collections of books and other media. Canadian
Journal of Information and Library Science, 28(4), 73-88.

Nilsson, SK (2012). Readers' reactions to emotionally evocative and morally provocative fiction: A study of young adults' readings of two short stories. Nordisk Tidsskrift for Informationsvidenskab og Kulturformidling, 1(1/2), 55-65.

Nilsson, SK (2014). Reading in a changing society: Some impact in the Swedish context. Reading in Changing Society. Tartu: University of Tartu Press, 118-132.

Olsen, AN, Kleivset, B \& Langseth, H (2013). E-book readers in higher education: Student reading preferences and other data from surveys at the University of Agder. SAGE Open, 3(2), 2158244013486493. http://dx.doi. org $/ 10.1177 / 2158244013486493$

Pattuelli, MC \& Rabina, D (2010). Forms, effects, function: LIS students' attitudes towards portable e-book readers. Aslib Proceedings, 62(3), 228-244. http://dx.doi.org/10.1108/00012531011046880

Pedersen, NU \& Lund, H (2009). Eyetrack $3 F$ : Sådan loeser $3 F^{\prime}$ ere på nettet: Udvikling af netvenlige tekstformer med eyetrack testing. København: 3F.

Pharo, N, \& Nordlie, R (2005). Context matters: An analysis of assessments of XML documents. I F. Crestani \& I. Ruthven (Red.), Context: Nature, impact, and role, Lecture Notes in Computer Science (s. 238-248). Springer Berlin Heidelberg. Hentet fra http://dx.doi.org/10.1007/11495222_19

Pold, SB (2012). Den digitale litterære kultur og bibliotekerne: Stram forretningsmodel eller litterær udfordring? En diskussion ud fra to aktuelle bogformater. Nordisk Tidsskrift for Informationsvidenskab og Kulturformidling, 1(1/2), 19-30.

Rayner, K (1998). Eye movements in reading and information processing: 20 years of research. Psychological Bulletin, 124(3), 372-422. http://dx.doi. org/10.1037/0033-2909.124.3.372

Regnell, A (2014, 23. januar). Vi måste få ett slut på e-bokseländet. DIK - det kreativa facket. Hentet fra 
dik.se/nyheter/2014/jan/"vi-maaste-faa-ett-slut-paae-bokselaendet"/

Riksdagen (2013). En bok är en bok är en bok? - en fördjupningsstudie av e-böckerna i dag. Rapport från riksdagen. Stockholm: Riksdagstryckeriet. Hentet fra http://www.riksdagen.se/sv/Dokument-Lagar/Utredningar/Rapporter-fran-riksdagen/Rapport-fran-riksdagen-201314_H10WRFR3/

Rogers, EM (2003). Diffusion of innovations. New York: Free Press.

Schmidt, SK (2011). En eye-tracker undersøgelse af laesehastighed på Kindle, iPad og papir (Bacheloropgave). København: Det Informationsvidenskabelige Akademi.

Siegenthaler, E, Schmid, L, Wyss, M \& Wurtz, P (2012). LCD vs. e-ink: An analysis of the reading behavior. Journal of Eye Movement Research, 5(3), $1-7$.

Siegenthaler, E, Wurtz, P, Bergamin, P, \& Groner, $\mathrm{R}$ (2011). Comparing reading processes on e-ink displays and print. Displays, 32(5), 268-273. http:// dx.doi.org/10.1016/j.displa.2011.05.005

Smidt, JK (2002). Mellom elite og publikum: Litterar smak og litteraturformidling blant bibliotekarer i norske folkebibliotek. Acta humaniora. Oslo: Det humanistiske fakultet, Universitetet i Oslo.

SOU 2012:65. (2012, 27. september). Läsandets kultur. Stockholm: Kulturdepartementet. Hentet fra http://www.regeringen.se/sb/d/15600/a/200257

Svedjedal, J (2012). Biblioteken och bokmarknaden: Från folkskola till e-böcker. Stockholm: Svenska Förläggareföreningen. Hentet fra http://forlaggare.se/ sites/default/files/Biblioteken\%20och\%20bokmarknaden\%20rapport_1.pdf

Svenska Förläggareföreningen (2013). Fritt eller gratis? Den digitala bokens framtid. Stockholm: Svenska Förläggareföreningen. Hentet fra http://forlaggare.se/sites/default/files/Fritt\%20eller\%20gratis_0.pdf
Tveit, ÅK (2004). Innganger: Om lesing og litteraturformidling. Bergen: Fagbokforlaget.

Tveit, ÅK \& Mangen, A (2013). A Joker in the class: Young readers' attitudes and preferences to reading on different platforms. Sendt utgiver, under vurdering.

Vaage, OF (2013). Norsk mediebarometer 2012. Oslo: Statistisk sentralbyrå. Hentet fra http://www. ssb.no/kultur-og-fritid/artikler-og-publikasjoner/_attachment/116447

van der Weel, A (2010). e-Roads and i-Ways: A sociotechnical look at user acceptance of ebooks. LOGOS: The Journal of the World Book Community, 21(3-4), 47-57. http://dx.doi. org/10.1163/095796511X559945

Winston, B (1998). Media technology and society: A history: From the telegraph to the Internet. London: Routledge.

Woody, WD, Daniel, DB \& Baker, CA (2010). Ebooks or textbooks: Students prefer textbooks. Computers \& Education, 55(3), 945-948. http://dx.doi. org/10.1016/j.compedu.2010.04.005

Worsøe-Schmidt, L (1994a). Litteraturens situation og litteraturpolitikken 1961-93. Kulturens politik. Århus: Nordisk Kultur Institut, Klim.

Worsøe-Schmidt, L (1994b). Forfatter i Danmark 1894-1994. København: Dansk Forfatterforening.

Worsøe-Schmidt, L (1999). At bloese med mel i munden: Litteraturpolitik i Danmark. Skrifter fra Center for Kulturpolitiske Studier. København: Danmarks Biblioteksskole, Center for Kulturpolitiske Studier.

Worsøe-Schmidt, L \& Pedersen, G (2002). Det danske bogmarked: Rapport 2002. København: Kulturstyrelsen for Kulturministeriet.

YouGov Danmark A/S (2012). Det danske bogmarked 2012 - på vej hvorhen? En kvantitativ og kvalitativ undersøgelse af danskernes forhold til bøger. Hentet fra http://ipaper.ipapercms.dk/HKHandel/UndersgelseafbogmarkedetYouGov2012/ 